\title{
EMOTIONS OF STUDENTS INVOLVED IN CASES OF BULLYING ${ }^{1}$
}

\author{
Julliane Messias Cordeiro Sampaio², Gabriela Valente Santos ${ }^{3}$, Wanderlei Abadio de Oliveira4, Jorge Luiz da \\ Silva $a^{5}$ Marcelo Medeiros ${ }^{6}$, Marta Angélica Iossi Silva
}

${ }^{1}$ Research funded by the Brazilian Council for Scientific and Technological Development (CNPq), process 482842/2010-5.

${ }^{2}$ Doctoral student, Graduate Program in Public Health Nursing, Universidade de São Paulo at Escola de Enfermagem de Ribeirão Preto (EERP/USP). Ribeirão Preto, São Paulo, Brazil. E-mail: enfajulliane@usp.br

${ }^{3}$ Undergraduate student at EERP/USP. PIBIC/CNPq grantee. Ribeirão Preto, São Paulo, Brazil. E-mail: gabrielavalente@gmail.com

${ }^{4}$ Doctoral student, Graduate Program in Public Health Nursing at EERP/USP. CAPES grantee. Ribeirão Preto, São Paulo, Brazil. E-mail: wanderleio@usp.br

${ }^{5}$ Doctoral student, Graduate Program in Public Health Nursing at EERP/USP. FAPESP grantee. Ribeirão Preto, São Paulo, Brazil. E-mail: jorgelsilva@usp.br

${ }^{6}$ Ph.D. in Nursing. Associate Professor, Faculty of Nursing, Universidade Federal de Goiás. Goiânia, Goiás, Brazil. E-mail: marcelo@ fen.ufg.br

${ }^{7}$ Ph.D. in Nursing and Public Health. Associate Professor, Maternal-Infant Nursing and Public Health Department at EERP/ USP, São Paulo, Brazil. E-mail: maiossi@eerp.usp.br

ABSTRACT: The objective was to estimate the prevalence of school bullying and identify the emotions of students involved. In this cross-sectional and descriptive study, a questionnaire was applied to 232 sixth-grade students of a public school. The results show a large number of students involved in bullying (39.6\%): 22.2\% were victims and 17.4\% were aggressors. Anger was the most frequent emotion experienced by the victims when suffering aggression, while most aggressors reported that no emotions were experienced when abusing their peers. The high prevalence of bullying, its characteristics and the negative consequences that arise make it a public health problem. This study covers the importance of identifying emotions associated with school bullying, a subject seldom explored, which can contribute to the development of integral healthcare delivered to students.

DESCRIPTORS: Violence. Bullying. School health. Intersectorial action.

\section{PREVALÊNCIA DE BULLYING E EMOÇÕES DE ESTUDANTES ENVOLVIDOS}

RESUMO: Este artigo objetivou estimar a prevalência de bullying escolar e identificar as emoções dos estudantes envolvidos. Trata-se de um estudo transversal e descritivo, desenvolvido mediante a aplicação de um questionário em 232 estudantes do sexto ao nono anos do ensino fundamental de uma escola pública. Dentre os resultados encontrados, destaca-se a grande quantidade de participação dos estudantes investigados em atos de bullying (39,6\%), dos quais 22,2\% eram vítimas e 17,4\% agressores. A raiva foi a emoção prevalentemente experimentada pelas vítimas durante as agressões que sofriam. Já os agressores, em sua maioria, relataram que o fato de agredirem seus colegas não gerou emoções. A alta prevalência do bullying, suas características e as consequências negativas por ele acarretadas o configuram em problema de saúde pública. O estudo remete à importância da identificação das emoções associadas à ocorrência do bullying, tema ainda pouco explorado e que pode contribuir na construção do cuidado integral da saúde do escolar.

DESCRITORES: Violência. Bullying. Saúde escolar. Ação intersetorial.

\section{EMOCIONES DE LOS ESTUDIANTES QUE PARTICIPAN EN SITUACIONES DE ACOSO ESCOLAR}

\begin{abstract}
RESUMEN: Este estudio tuvo como objetivo estimar la prevalencia del acoso escolar y identificar las emociones de los estudiantes involucrados em su violencia. Se trata de un estudio descriptivo transversal, desarrollado con 232 estudiantes del sexto al noveno año de la escuela primaria en una escuela pública. Entre los resultados, la participación de los estudiantes en intimidación fue de 39,6\%, $22,2 \%$ eran víctimas y 17,4\% eran agresores. La ira es la emoción predominante experimentada por las víctimas. En cuanto a los autores, la mayoría informó que no sintió emociones mientras que la agresión hacia sus compañeros. La alta prevalencia del acoso escolar, sus características y las consecuencias negativas que conlleva lo tiene configurarlo en un problema de salud pública. El estudio apunta a la importancia de identificar las emociones asociadas a la ocurrencia de acoso escolar, aún no exploradas tema que puede ayudar en la construcción de la salud integral de la escuela.
\end{abstract}

DESCRIPTORES: Violencia. Acoso escolar. Salud escolar. Acción intersectorial. 


\section{INTRODUCTION}

The quality of the interpersonal relationships experienced in school is an important aspect for the healthy development of children and adolescents. That is so because, besides their commitment to formal education, schools serve as contexts for socialization among peers, allowing the children and adolescents to acquire relational knowledge and perform social skills that are hard to achieve in other environments that do not offer opportunities for more direct interaction with peers. ${ }^{1}$ In the interaction processes among the students, however, sometimes, situations may occur that are marked by conflict or violence. The participation in or exposure to school violence provoke emotional responses that can induce the students to fight or flight behaviors, which interfere negatively in their health and in their socialization and learning processes. $^{2}$

One of the most common types of violence among peers in school is bullying, which is characterized by repeated aggressions, unbalanced power between aggressors and victims and intentional actions. ${ }^{3}$ According to that definition, aggressions practiced between students with similar (physical, psychological or verbal) power, in terms of possible aggressive attacks against colleagues and/or protection against the violence suffered, do not represent bullying.

This type of violence develops in dynamic interaction contexts, in which the students play specific roles: aggressors, victims and witnesses. The aggressions practiced are classified in three distinct categories: physical (punches, kicks, pushes), verbal (swears, pejorative names, gossip and insults) and psychological (social exclusion/ isolation of the colleague). ${ }^{4-5}$

The occurrence of this phenomenon can be verified in practically all schools around the world. ${ }^{6}$ A cross-cultural research developed in 35 European and North American countries identified a prevalence of victimization ranging between $4.1 \%$ and $36.3 \% .^{7}$ In Brazil, in the National School Health Survey (PeNSE - 2012), it was identified that $7.2 \%$ of the investigated students affirmed that they were frequent victims and $20.8 \%$ practiced some kind of bullying against colleagues. ${ }^{8}$ The high occurrence and frequency rates of bullying, associated with the different negative consequences it entails for the victims, witnesses and aggressors' teaching-learning process, health and quality of life, contributes for bullying to be considered a public health problem. ${ }^{9}$
The scientific literature has demonstrated that the exposure to bullying in the school context can cause different physical and mental health problems. ${ }^{3,5}$ Concerning the victims and witnesses, they are more prone to constant fear, anxiety, negative thinking, low self-esteem, depression, selfpunishment, psychosomatic symptoms (headaches, dizziness, stomach problems, among others) and suicidal ideas. ${ }^{10}$ The aggressors, in turn, tend to engage in situations of domestic violence, psychoactive substance abuse, vandalism and infractions. ${ }^{11-13}$

The consequences of engaging in situations of bullying can accompany the students' life and make them attribute senses, meanings and/or respond to the social relations. In addition, it is important to highlight that, although chronic health conditions associated with bullying may take some time to appear, the social consequences, such as solitude, social exclusion, low school performance, repeated absences from class, drop-out, among others, occur immediate and negatively influence the students' quality of life and education. ${ }^{14}$

Despite the harmful effects of bullying, most victims do not denounce the aggressions to family members or teachers, either out of fear of the aggressors' reaction, fear that the adults will not believe them or due to the perception that their situation is normal. Thus, the aggressions can go by for many years without families and school authorities' noticing them. ${ }^{15}$ Therefore, efforts towards the early identification of bullying, as a sign of alert for other personal, social, school and health development problems, are fundamental for its control and eradication in the school context. As the negative effects of the aggressions do not disappear over time, it is also extremely relevant to make efforts to investigate the factors associated with their occurrence and continuity. ${ }^{16}$

In that sense, the emotions represent aspects that, from a personal perspective, can help to clarify the harmful effects of the aggressions on victims and aggressors. That is so because, in different situations, social interaction underlie the emotional conditions, determining the occurrence of emotions, the way they will be expressed and the consequences they entail, ${ }^{17}$ as the emotional conditions stimulate actions that determine physiological activity patterns that support behavior. In other words, the emotions exert a mediating effect between external and internal events, modulating the reaction and behavioral response to bullying. ${ }^{18}$

In summary, two types of emotions are identified: primary and secondary. People universally 
manifest the primary emotions (anger, sadness, fear, happiness, among others). On the other hand, secondary emotions are linked to social and cultural influences (shame, guilt, pride, among others).${ }^{19}$ With regard to victims of bullying, the study of emotions helps to understand the results of the aggressions they are victims of, the associated stress, as well as the behavioral response they will issue in view of the aggressors, which can both interrupt the aggressions and aggravate their frequency and intensity. Concerning the aggressors, understanding the emotions related to the aggressive acts they practice can help them to develop greater self-mastery and to relate with their peers in a non-violent manner. ${ }^{20}$

In view of the above, this kind of research, aiming to know what the students involved in situations of bullying (victims and aggressors) feel is necessary not only for theoretical reasons, but also based on an applied perspective, ${ }^{10,21}$ as the construction of knowledge on the theme can support evidence-based prevention, health promotion and development practices. This knowledge can also support strategies to cope with bullying, aiming to promote comprehensive and intersectoral actions, especially between health and education, mainly considering that the emotions associated with episodes of bullying have been hardly investigated in the literature. ${ }^{18}$ Therefore, the objectives in this study were to estimate the prevalence of school bullying and identify the emotions of the students involved.

\section{METHOD}

A cross-sectional and descriptive research was developed based on the application of a structured questionnaire in a stratified random sample, consisting of 232 students from the sixth until the ninth year of basic education at a state-owned public school in an interior city in the State of São Paulo. The school was selected by convenience, since it was serving in a research and community service project, linked to the research group the researchers are affiliated with.

It should be highlighted that students who indicated they engaged in situations of aggression, threat, humiliation or social exclusion for three times or more $(\geq 3)$ in the last 30 days were considered as victims of bullying. ${ }^{7}$ To calculate the sample size, the following parameters were considered: student population at the school equal to 571 students, prevalence of the outcome (occurrence of three or more episodes of bullying known in the last 30 days equal to $50 \%$ ), sampling error of five percentage points and $95 \%$ confidence inter$\operatorname{val}(a=0.05)$. In view of the adjustment for a finite population and adding 15\% for possible losses or refusals, the final sample consisted of 232 students.

As criteria to participate in the research, first, the student should be enrolled, attend classes, be present on the day the questionnaire was applied and present the Free and Informed Consent Form, signed by a responsible caregiver. The data were collected anonymously through the application of a self-applied questionnaire. This tool was elaborated based on scientific evidence and other questionnaire, constructed to investigate emotions associated with bullying in the school context. ${ }^{22-24}$

After its elaboration, the questionnaire was submitted to three experts in school violence for assessment, who performed the structural and content analysis. In addition, the researchers tested the appropriateness of the questions to the understanding of the target public (adolescents) through a pretest in a group of three students (about 10\% of the sample, $n=23$ ), who were also students in basic education. These students were randomly selected from another school in the state-owned public network that possessed characteristics similar to the school where the definitive study was undertaken.

The final version of the questionnaire included 19 questions, subdivided in three parts: 1) Identification (age, sex, school year, failure and skin color); 2) Characterization of victimization (type of aggression suffered, frequency, injury sites, age and ex of aggressors, search for help from adults, and emotions related to the aggression); and 3) Characterization of aggressions (type of aggression, frequency, places of occurrence, age and sex of aggressors and emotions related to the victim). Examples of some questions are: have you ever been assaulted, threatened, humiliated or excluded by colleagues in school? How did you feel when you were assaulted, threatened, humiliated or excluded by colleagues? Have you ever assaulted, threatened, humiliated or excluded a colleague in school? How did you feel when you assaulted, threatened, humiliated or excluded a colleague? The questions were multiple choice and the answers regarding the emotions were limited to five options (discouragement, fear, anger, sadness, shame and none), appointed in the literature as the most prevalent. Nevertheless, an option was given to add other options if the emotion experienced was not addressed in the options listed. 
The researchers collected the data during the students' class time, through meetings with the selected class groups (sixth to ninth year of basic education). The researchers presented the questionnaire and then permitted its completion, taking an average 30 minutes. Throughout the procedure, the students were monitored and any doubts were clarified.

For data analysis, the participants' answers were included in a Microsoft Excel worksheet for descriptive statistical treatment. This is basically aimed at summarizing information, so as to permit a global view of the variation in the scores. The results were organized and described in two ways: tables and descriptive measures.

The school board authorized the development of the research and the project received approval from the Institutional Review Board at the Escola de Enfermagem de Ribeirão Preto da Universidade de São Paulo - EERP-USP (Protocol 1422/2011). Before the data collection, all students received information about the research, and anyone interested in participating received the Free and Informed Consent Form, to be signed by a responsible caregiver.

\section{RESULTS}

As regards the distribution of the sociodemographic characteristics (age, school year, sex, failure and skin color), presented in table 1, the age of the students in the research sample $(n=232)$ varied between 10 and 18 years, with a concentration between 13 and 15 years (58.6\%), which can be justified by the fact that the majority was of more advanced age, i.e. the eighth and ninth years $(54.3 \%)$. As regards the gender distribution, most subjects were female $(53.0 \%)$. It was observed that more than three quarters of the participants indicated they had never failed any year $(76.3 \%)$. Concerning the skin color, a predominance of mulatto and white participants is noted $(81.8 \%)$.

Specifically concerning the involvement in situations of bullying, $22.2 \%$ of the participants fit into the victim profile and $17.4 \%$ into the aggressor profile. The distribution of the victimization between the sexes was equivalent. As regards the victims' age, a greater concentration was found at the age of 13 years $(64.8 \%)$. For the aggressors, the percentage of boys (54.9\%) was higher when compared to girls (45.1\%). Most aggressors were 14 years old $(46.8 \%)$.
Table 1 - Characterization of the students according to school year, sex, age range and number of failures. Ribeirão Preto-SP, 2014

\begin{tabular}{lrr}
\hline Variable & $\mathrm{n}$ & $\%$ \\
\hline Sex & & \\
Male & 109 & 47,0 \\
Female & 123 & 53,0 \\
Age & & \\
10 to 12 & 90 & 38,8 \\
13 to 15 & 136 & 58,6 \\
16 to 18 & 6 & 2,6 \\
School year & & \\
6th & 52 & 22,4 \\
7th & 54 & 23,3 \\
8th & 61 & 26,3 \\
9th & 65 & 28,0 \\
Skin color & & \\
White & 87 & 37,5 \\
Black & 32 & 13,8 \\
Mulatto & 103 & 44,3 \\
Yellow & 5 & 2,2 \\
Indigenous & 5 & 2,2 \\
School failure & & \\
None & 177 & 76,3 \\
One & 35 & 15,1 \\
Two & 14 & 6,0 \\
Three or more & 6 & 2,6 \\
\hline & & \\
\hline
\end{tabular}

As regards the nature of the aggressions the victims suffered, verbal aggressions were prevalent $(68.2 \%)$, particularly insults, swears and nicknames. Among the girls, the aggressions were mostly focused on personal characteristics or other situations related to the female condition, like the use of make-up for example. On the opposite, among the girls, the aggressions converged in issues related to the skin color. They also mentioned, to a lesser extent, the disappearance of personal objects or their handling by colleagues without permission.

On the other hand, the focus on the nature of the aggressions practiced indicates that, for the female sex, the verbal aggressions, mainly the nicknames, represent a tonic (53.8\%) while, for the boys, the physical aggressions, such as punches, pushes and kicks are more common $(43.6 \%)$. They also mention theft or damage to colleagues' personal objects.

As presented in table 2, anger was the prevailing emotion for the victims when attacked, for the girls $(70.4 \%)$ as well as the boys $(52.0 \%)$. The information regarding discouragement should 
Sampaio JMC, Santos GV, Oliveira WA, Silva JL, Medeiros M, Silva MAI

equally be highlighted, with higher levels for girls. This may mean that they do not feel in the conditions needed for self-protection, which may also induce them to lose courage to study or lose classes in the attempt to escape from new aggressions. Sadness and shame also stood out for male and female participants. These emotions can cause a feeling of powerlessness and, thus, intensify the suffering experienced.

Table 2 - Distribution of bullying victims according to the emotion generated by the aggression suffered. Ribeirão Preto-SP, 2014

\begin{tabular}{lcccc}
\hline \multirow{2}{*}{ Emotions } & \multicolumn{2}{c}{ Female $(\mathbf{n}=\mathbf{2 7})$} & \multicolumn{2}{c}{ Male $(\mathbf{n}=\mathbf{2 5})$} \\
& $\mathbf{n}$ & $\mathbf{\%}$ & $\mathbf{n}$ & $\%$ \\
\hline None & 03 & 11.1 & 03 & 12.0 \\
Fear & 03 & 11.1 & 02 & 8.0 \\
Discouragement & 11 & 40.7 & 03 & 12.0 \\
Sadness & 15 & 55.5 & 07 & 28.0 \\
Shame & 15 & 55.5 & 06 & 24.0 \\
Anger & 19 & 70.4 & 13 & 52.0 \\
\hline
\end{tabular}

The results revealed that the victims who mentioned feeling sad also felt embarrassed when they were assaulted. Participants who were targets of verbal aggressions manifested discouragement and lack of desire to go to school. Anger was more present for the victims involved in situations of gossip. Not feeling any emotion was a preponderant response in 11-year-old victims in the sixth year of basic education.

As regards the emotions the aggressors felt at the moment of the aggressions they practiced (Table 3), not feeling any emotion prevailed for both sexes, indicating the absence of identification with victim, perhaps because they do not acknowledge the extent and severity of the violence for the victimized students' physical, emotional or social wellbeing. This absence of empathy can contribute for the aggressions to gain intensity without any intervention to avoid their continuity.

The results reveal that the students who physically assessed their peers demonstrated that they felt no emotions or felt anger during the aggressions. On the other hand, students who assaulted verbally revealed more shame. Most aggressors were concentrated in the sixth school year, at the age of 11 years.
Table 3 - Distribution of aggressors of bullying according to the reported emotions produced during the aggressions. Ribeirão Preto-SP, 2014

\begin{tabular}{lcccc}
\hline \multicolumn{1}{c}{ Emotions } & \multicolumn{2}{c}{ Female $(\mathbf{n}=\mathbf{1 2})$} & \multicolumn{2}{c}{ Male $(\mathbf{n}=\mathbf{2 7})$} \\
& $\mathbf{n}$ & $\mathbf{0}$ & $\mathbf{n}$ & $\%$ \\
\hline None & 03 & 25.0 & 11 & 40.7 \\
Fear & - & - & 02 & 7.4 \\
Discouragement & 03 & 25.0 & 01 & 3.7 \\
Sadness & 03 & 25.0 & 07 & 25.9 \\
Shame & 01 & 8.3 & - & - \\
Anger & 02 & 16.7 & 08 & 29.6 \\
\hline
\end{tabular}

\section{DISCUSSION}

In view of the study objectives, in the analyses, first, the results regarding the students' involvement in situations of bullying are highlighted, with a high prevalence (39.6\%), indicating a larger number of victims than aggressors. The total number of investigated students involved was higher than the result of $28.0 \%$ obtained in the National School Health Research undertaken in $2012 .{ }^{8}$ On the other hand, the frequency found in this study is in line with the results of other studies, which even concluded that the high prevalence of bullying in school contexts characterizes it as an important social and public health problem. These studies also signal that measures to prevent, cope with and control bullying in the school contexts need to be taken, considering its personal and contextual (micro and macro) determinants, through the convergence of intersectoral efforts, with a view to addressing the problem at the complexity level it presents. ${ }^{3,5,15,24}$

The investigated students' age, for victims as well as for aggressors, was concentrated around the age of 13-14 years, going against the consensus found in the literature which admits the existence of peaks of vulnerability to bullying at moments of transition in teaching. In the Brazilian reality, these correspond to the sixth year of basic education and the first year of secondary education, when students generally are 11 and 15 years old, respectively. ${ }^{3,5}$ This result needs to be interpreted with caution though, as most investigated students were in the most advanced school years (eighth and ninth). Thus, the small number of sixth-year participants may have influenced the results. 
Concerning the sex, boys demonstrated that they commit more aggressions than girls, in line with other studies..$^{24-27}$

Most acts of aggression practiced in the school context under investigation were verbal, which suggests an apparent contradiction with the data related to sex, as boys are expected to engage more in physical attacks, while girls are expected to practice more verbal aggressions. ${ }^{28}$ Nevertheless, this information may be interpreted in line with the proposals put forward in another Brazilian study ${ }^{5}$, which identified a prevalence of verbal aggressions independently from the aggressors' sex, as the school authorities generally interpret these as less serious and, therefore, less subject to severe punishment. Hence, both boys and girls can commit more verbal aggressions because these are mixed up with tricks or ordeals typical of the age. ${ }^{29}$

In view of the results found on the emotions produced in the context of bullying, the most prevailing response among the male and female victims was anger. Although the information on how the emotional conditions of children and adolescents in bullying situations are related to their reaction towards the aggression remain limited, it is clear that the emotions can function as catalysts of this process, stimulating more or less appropriate reactions to cope with the violence. ${ }^{10}$ Anger, for example, is associated with specific forms of action, such as fights, which can both interrupt the situation of violence and increase the number of aggressions if the victim does not have sufficient physical strength for the purpose of self-defense. ${ }^{18}$

Another possibility is that the anger stimulates the victims to reproduce the aggressions they were victims of in other students with less conditions for self-defense, from the physical, psychological or social viewpoint. Thus, the violence is expanded and intensified, generating a cycle of negative consequences for the entire school community, also considering that most of the students witness the aggressions committed against classmates. ${ }^{30}$ As perceived, social contact is school is also influenced by the emotions produced in the interrelations among the students. Therefore, it is fundamental to identify what emotions are preponderant in specific interpersonal relationship situations, like those marked by violence, to allow the school authorities to cope with them through the elaboration of more contextualized interventions. ${ }^{1}$
Two other emotions the victims experienced more intensely were: sadness and shame. In the bullying context, the sadness may indicate to the students that they are unsettled in the school environment, which can cause a feeling of inability to cope with the aggressions. The sadness also provides essential information related to the student's health and wellbeing, considering that, when experienced over extended period, it can cause physical (insomnia) and mental (depression) health problems. ${ }^{18}$ Shame, on the other hand, can induce the victims not to defend themselves out of fear of being the target of aggressions or humiliations repeatedly. It also discourages the request for help to classmates, teachers or family members. ${ }^{26}$

Demotivation, in turn, as a secondary emotion, influenced by social and cultural characteristics, emerges as a result of the existence of other primary emotions like sadness. It can influence the quality of the victims' relationships with colleagues and teachers, cause social isolation and impair the school performance. ${ }^{27}$ Fear, in turn, stimulates the adoption of measures to guarantee the safety but, in a high concentration, are associated with impotence in relation to self-defense and requests for help.

On the other hand, some victims mentioned not feeling any emotion during the aggressions they were victims of. This finding may indicate that they interpret the acts of violence as inoffensive tricks or as "normal" behaviors they have to bear to be part of social life with their peers. This signals a naturalizing conception of violence that makes it impossible to elaborate more critical readings of the contexts, which is essential for the healthy development process and to cope with the situations of violence.

For the aggressors, the response related to not feeling any emotion while practicing aggressions prevailed for both sexes, signaling the absence of identification with the victims. In these cases, the lack of empathy is related to the continuity of the bullying situation, as the aggressors do not understand or identify themselves with the suffering they are provoking in their classmates. ${ }^{10}$ This condition is particularly severe for the investigated boys, considering that most of them reported not feeling anything while assaulting their classmates. On the opposite, sadness, shame and demotivation can discourage the violence, because the aggressors understand the damage caused to the victims or the inappropriateness of 
their behavior to life in the school context. The results indicated that the female aggressors are more prone to demonstrating these emotions.

Based on the data obtained, it is observed that the aggressors also demand care, as they are subject to the consequences of the aggressions they practice. It is characteristic for them to display distancing and lack of adaptation to the school objectives, an overvaluation of violence as a way to gain power and social insertion, besides the maintenance of violent conducts in adult life. ${ }^{31}$ Some of the consequences bullying causes in the aggressors' adult life are drugs abuse, unemployment, criminal involvement and diagnosed antisocial personality. The victims, on the other hand, generally present depression, panic disorder and suicide. ${ }^{32}$ Therefore, the negative effects of bullying cannot be ignored or underestimated, and measures to contain and present aggressive behaviors need to be prioritized in comprehensive intervention that particularly involve students, school, family, community and health services.

Hence, knowledge about the emotions associated with bullying in victims and aggressors is an important starting point to support strategies to cope with this kind of violence, as it helps to understand the way the aggressions are received and the possible emotional reactions that result from them. In this respect, measures to promote the victims' self-esteem can help to defend themselves against the bullying. Similarly, actions that simulate greater bonding with classmates, relatives and teachers grant better conditions to report aggressions and request help, enabling them to break a cycle that is often perpetuated through silence. Concerning the aggressors, strategies to improve the social life, respect for difference and the encouragement of non-violent interactions are possible courses. In addition, other measures need to be implemented involving different sectors, with a view to the construction of comprehensive care practices that minimize the negative impact of bullying on the physical, emotional and school wellbeing of victims and aggressors. ${ }^{33}$

\section{FINAL CONSIDERATIONS}

The prevalence of bullying identified in this study supports the elaboration of programs to prevent or cope with this phenomenon in the context of the research reality. In addition, the identification of the emotions associated with the occurrence of bullying among peers in the school context contributed to understand a reality that has not been much explored yet in research on this theme. Delimiting the emotions generated in victims and aggressors is fundamental to understand the way the victims experience the aggressions and the role they play in the aggressors, with a view to modulating the continuity or interruption of the violent situations they practice. This information can support the planning of interventions that are more in tune with the impact of bullying in the physical and mental health and quality of the students' school experience. They can also represent a starting point for future research on the relations between bullying and school health, as well as encourage the construction of theoretical models to clarify these issues.

As the consequences of bullying are not limited to the school period, but often entail a cascade effect, extending to the professional reality for example, help for the victims and the aggressors, with a view to raising their awareness on the emotions they experience, is important for them to feel capable of coping with the diverse situations of violence or conflicts they are involved in. Nevertheless, it is important to highlight that, if they are circumscribed to the individual level only, these actions can lose efficacy in function of the social and institutional aspects that affect the school violence.

Thus, an approach based on public health principles needs to involve other sectors and include the entire school community, through the development of interdisciplinary and intersectoral work. Examples are the activities resulting from the political initiatives to insert health professionals in the school environment to develop health promotion and education strategies. These measures can provide the students with an environment that is perceived as safe and favorable to maintain their mental health and consolidate personal skills to adequately cope with conflict situations.

\section{REFERENCES}

1. Sánchez V, Ortega R, Menesini E. La competencia emocional de agresores y víctimas de bullying. An Psicol. 2012 Jan; 28(1):71-82.

2. Wynne SL, Joo HJ. Predictors of school victimization: individual, familial, and school factors. Crime Delinquency. 2011 Mai-Jun; 37(3):458-88.

3. Olweus D. School bullying: development and some important challenges. Annu Rev Clin Psycho. 2013 Mar; 9:751-80. 
4. Pingoelo I, Horiguela MLM. Bullying na sala de aula. De Jure. 2010 Jul-Dez; 15(2):145-56.

5. Silva JL, Oliveira WA, Bazon MR, Cecilio S. Bullying na sala de aula: percepção e intervenção de professores. Arq Bras Psicol. 2013 Jan-Abr; 65(1):121-37.

6. Harel-Fisch Y, Walsh SD, Fogel-Grinvald H, Amitai G, Pickett W, Molcho M, et al. Negative school perceptions and involvement in school bullying: a universal relationship across 40 countries. J Adolescence. 2010 Ago-Set; 34(4):639-52.

7. Due P, Merlo J, Harel-Fisch Y, Damsgaard MT, Holstein BE, Hetland J, et al. Socioeconomic inequality in exposure to bullying during adolescence: a comparative, cross-Sectional, multilevel study in 35 countries. Am J Public Health. 2009 Mai; 99(5): 907-14.

8. Ministério da Saúde (BR). Pesquisa Nacional de Saúde do Escolar [online]. Brasilía (DF): IBGE; 2012 [acesso 2013 Out 1]. Disponível em: http:// www.ibge.gov.br/home/estatistica/populacao/ pense/2012/pense_2012.pdf

9. Kukaswadia A, Craig W, Janssen I, Pickett W. Bullying as a mediator of relationships between adiposity status and weapon carrying. Int J Public Health. 2012 Jun-Jul; 57(3):505-12.

10. Barhight LR, Hubbard JA, Hyde CT. Children's physiological and emotional reactions to witnessing bullying predict bystander intervention. Child Dev. 2013 Jan-Fev; 84(1):375-90.

11. Levin J, Madfis E. Mass murder at school and cumulative strain: a sequential model. Am Behav Sci. 2009 Mai; 52(9):1227-45.

12. Lynne-Landsman SD, Graber JA, Nichols TR, Botvin GJ. Trajectories of aggression, delinquency, and substance use across middle school among urban, minority adolescents. Aggressive Behav. 2011 AbrMai; 37(2):161-76.

13. Zaine I, Reis MJD, Padovani RC. Comportamentos de bullying e conflito com a lei. Estud Psicol. 2010 Jul-Set; 27(3):375-82.

14. Popp AM. The effects of exposure, proximity, and capable guardians on the risk of bullying victimization. Youth Violence Juveline Justice. 2012 Out-Dez; 10(4):315-32.

15. Anthony BJ, Wessler SL, Sebian JK. Commentary: Guiding a public health approach to bullying. J Pediatr Psychol. 2010 Nov-Dec; 35(10):1113-15.

16. Sourander A, Klomek A, Kumpulainen K, Puustjärvi A, Elonheimo H, Ristkari T, et al. Bullying at age eight and criminality in adulthood: Findings from the Finnish Nationwide 1981 Birth Cohort Study. Soc Psych Psych Epid. 2011 Dez; 46(12):1211-9.

17. Bonomo MAS, Araujo TCCF. Psicologia aplicada à cardiologia: um estudo sobre emoções relatadas em exame de Holter. Psic Teor Pesq. 2009 Jan-Mar; 25(1):65-74.

18. Vie TL, Glasø L, Einarsen S. How does it feel? Workplace bullying, emotions and musculoskeletal complaints. Scand J Psychol. 2012 Abr-Mai; 53(2):65173.

19. Roazzi A, Dias MGBB, Silva JO, Santos LB, Roazzi MM. O que é emoção? Em busca da organização estrutural do conceito de emoção em crianças. Psicol Reflex Crit. 2011 Jan-Mar; 24(1):51-61.

20. Pavarini G, Loureiro CP, Souza DH. Compreensão de emoções, aceitação social e avaliação de atributos comportamentais em crianças escolares. Psicol Reflex Crit. 2011 Jan-Mar; 24(1):135-43.

21. Pereira BO. Para uma escola sem violência: estudo e prevenção das práticas agressivas entre crianças. $2^{\mathrm{a}}$ ed. Braga (Portugal): FCT; 2008.

22. Observatório da infância [página na Internet]. Rio de Janeiro (RJ); 2009 [acesso 2009 Mai 17]. Disponível em: www.observatoriodainfancia.com.br

23. Kidscape [página da internet]. London (UK); 2009 [acesso 2009 Mai 17]. Disponível em: http:/ /www. kidscape.org.uk/

24. Ttofi MM, Farrington, DP. Effectiveness of schoolbased programs to reduce bullying: a systematic and meta-analytic review. J Exp Criminology. 2011 Mar-Mai; 7(1):27-56.

25. Bandeira CM, Hutz CS. Bullying: prevalência, implicações e diferenças entre os gêneros. Psicol Esc Educ. 2010 Jan-Jun; 16(1):35-44.

26. Garner PW, Hinton TS. Emotional display rules and emotion self-regulation: associations with bullying and victimization in community-based after school programs. J Community Appl Soc. 2010 Nov-Dez; 6(6):480-96.

27. Moura DR, Cruz ACN, Quevedo LA. Prevalência e características de escolares vítimas de bullying. J Pediat. 2011 Jan-Fev; 87(1):19-23.

28. Cullen FT, Unnever JD, Hartman JL, Turner MJ, Agnew R. Gender, bullying victimization, and juvenile delinquency: a test of General Strain Theory. Victims Offenders. 2008 Out-Dez; 3(4):346-64.

29. Hernandez D, Floden L, Bosworth K. How safe is a school? An exploratory study comparing measures and perceptions of safety. J School Violence. 2010 Out-Dez; 9(4): 357-74.

30. Janosz M, Archambault I, Pagani LS, Pascal S, Morin AJ, Bowen F. Are there detrimental effects of witnessing school violence in early adolescence? J Adolescent Health. 2008 Dez-Jan; 43(1):600-8.

31. Bourke S, Burgman I. Coping with bullying in Australian schools: how children with disabilities experience support from friends, parents and teachers. Disabil Soc. 2010 May; 25(3):359-71. 
32. Hertz MF, Donato I, Wright J. Bullying and suicide: a public health approach. J Adolescent Health. 2013 Jul; 53(1Suppl):S1-3.
33. Lopes MSV, Saraiva KRO, Fernandes AFC, Ximenes LB. Análise do conceito de promoção da saúde. Texto Contexto Enferm. 2010 Jul-Set; 19(3): 461-8. 